\title{
IDENTIFIKASI KARAKTERISTIK ANAK PUTUS SEKOLAH DI JAWA BARAT DENGAN REGRESI LOGISTIK*
}

\author{
Tina Aris Perhati $^{1}$, Indahwati ${ }^{2 \ddagger}$, Budi Susetyo ${ }^{3}$ \\ ${ }^{1}$ Dept. of Statistics, Bogor Agricultural University (IPB), Indonesia, tina.ariez@gmail.com \\ ${ }^{2}$ Dept. of Statistics, Bogor Agricultural University (IPB), Indonesia, indahwati@ipb.ac.id \\ ${ }^{3}$ Dept. of Statistics, Bogor Agricultural University (IPB), Indonesia, budisu5@ipb.ac.id \\ $\ddagger$ corresponding author
}

\section{Indonesian Journal of Statistics and Applications \\ Vol 1 No 1 (2017), 56 - 65}

Copyright (c) 2017 Tina Aris Perhati, Indahwati, Budi Susetyo. This is an open-access article distributed under the Creative Commons Attribution License, which permits unrestricted use, distribution, and reproduction in any medium, provided the original work is properly cited.

\begin{abstract}
School dropouts are the problem in education which is the condition of children who do not have the opportunity to complete their education that they couldnt obtain degree certificate due to certain factors. Based on SUSENAS 2013, there is $2.15 \%$ of children aged 7-15 years old in West Java who dropped out of school. Three aspects that have great potential on the incidence of school dropouts are characteristic of social, economy, and demography. This study uses logistic regression analysis to determine the effect of school dropouts by the three aspects. The results of logistic regression analysis at $5 \%$ significance level indicates that the characteristics of social, economy, and demography that have significant effect on the incidence of school dropouts are the low education of household head, more than four household members, less than the poverty line household expenditure per capita, residence location in urban areas, and boys. The resulting model is sufficient for estimation with the sensitivity value of $70.20 \%$ and the area under the ROC curve of $76.42 \%$.
\end{abstract}

Keywords: logistic regression, ROC curve, school children, sensitivity.

*Received Jun 2017; Accepted Jul 2017; Published online on Oct 2017 


\section{Pendahuluan}

Putus sekolah merupakan seseorang yang tidak dapat menyelesaikan pendidikan atau berhenti bersekolah dalam suatu jenjang pendidikan sehingga belum memiliki ijazah atau tanda tamat belajar pada jenjang pendidikan tersebut (KPP dan PA 2013). Anak putus sekolah sangat bertolak belakang dengan undang-undang (UU) tentang hak dan kewajiban warga negara no. 20 tahun 2003 pasal (6) ayat (1), yaitu setiap warga negara yang berusia 7 hingga 15 tahun wajib mengikuti pendidikan dasar yaitu SD/sederajat dan SMP/sederajat. Berdasarkan uraian UU tersebut, pendidikan dasar sering dikaitkan dengan wajib belajar sembilan tahun yang merupakan hak setiap warga negara usia 7 hingga 15 tahun yang memiliki peran penting untuk generasi penerus bangsa.

Program yang dibuat dan yang dilaksanakan pemerintah pun bermacam-macam untuk menunjang wajib belajar sembilan tahun, akan tetapi masih saja ditemui anak yang putus sekolah. Berdasarkan laporan UNICEF tahun 2012 sekitar 2.3 juta anak Indonesia usia 7 hingga 15 tahun tidak bersekolah dan $42 \%$ anak putus sekolah tersebar di tiga provinsi besar yaitu Jawa Timur, Jawa Tengah, dan Jawa Barat. Namun pada tahun berikutnya Jawa Barat memiliki angka putus sekolah tertinggi di Pulau Jawa 8.64\%, lebih tinggi dari rata-rata nasional $7.37 \%$ (SUSENAS 2013 diolah). Oleh karena itu, fokus penelitian ini ditujukan pada provinsi Jawa Barat.

Penelitian sebelumnya tentang anak putus sekolah (Astuti et al. 2013) di Kecamatan Jangka Kabupaten Bireun Provinsi Nanggroe Aceh Darussalam masalah utamanya pada aspek ekonomi keluarga (Grahacendikia 2009), dan hasil penelitian (Choiriyah 2009) di Surabaya Utara Provinsi Jawa Timur yang mempengaruhi tingginya angka putus sekolah adalah aspek ekonomi dan aspek demografi (jenis kelamin). Oleh karena itu, penelitian ini akan mengambil tiga aspek yang diduga mempengaruhi kejadian anak putus sekolah yaitu aspek sosial, ekonomi, dan demografi dengan menggunakan analisis regresi logistik. Regresi logistik adalah salah satu alat analisis dalam statistika yang merupakan bentuk khusus dari analisis regresi dengan peubah respon bersifat kategorik yaitu putus sekolah dan tidak putus sekolah, sedangkan peubah-peubah penjelas bersifat kontinu maupun kategorik (Agresti 2002).

\section{Metodologi}

\subsection{Data}

Penelitian ini menggunakan data hasil Survei Sosial Ekonomi Nasional (SUSENAS) Badan Pusat Statistik (BPS) Provinsi Jawa Barat tahun 2013, terdapat 22441 sampling unit atau rumah tangga. Adapun yang menjadi unit amatan adalah rumah tangga yang mempunyai anak usia 7 hingga 15 tahun yang berjumlah 9224 unit amatan dengan 11736 anak. Pengertian putus sekolah didefinisikan dari partisipasi sekolah anak yang tidak bersekolah lagi dan kepemilikan ijazah terakhir yang dimilikinya. Sebanyak 252 anak putus sekolah atau 2.15\% dari 11736 anak di Jawa Barat. Analisis yang dilakukan menggunakan tujuh peubah penjelas pada Tabel 3 dan satu peubah respon yaitu status sekolah terdiri dari dua kategorik yaitu anak tidak putus sekolah (0) dan anak putus sekolah (1). Dibawah ini merupakan peubah-peubah penjelas yang digunakan dan nilai kategori untuk masingmasing peubah penjelas: 
Tabel 1: Peubah-peubah penjelas yang digunakan

\subsection{Metode}

Beberapa tahapan yang dilakukan dalam penelitian ini adalah:

1. Melakukan pengkategorian beberapa peubah penjelas yang numerik

2. Melakukan analisis statistika deskriptif untuk memperoleh gambaran umum peubah penjelas yang digunakan

3. Membentuk dugaan model regresi logistik biner, kemudian melakukan pengujian parameter secara simultan dengan statistik uji-G untuk mengetahui peran seluruh peubah di dalam model

4. Melakukan pengujian parameter secara parsial dengan statistik uji Wald untuk mengetahui peran masing-masing peubah penjelas terhadap peubah respon.

5. Menginterpretasi koefisien model regresi logistik biner dengan odds rasio.

6. Menguji kebaikan model dengan tabel ketepatan klasifikasi dan kurva ROC

\section{Hasil dan Pembahasan}

\subsection{Gambaran Umum Data}

Berdasarkan hasil SUSENAS tahun 2013, terdapat 11736 anak berusia 7-15 tahun di Jawa Barat, yang terdiri dari 8289 anak berpendidikan SD/sederajat dan 3447 anak berpendidikan SMP/sederajat. Anak putus sekolah SD/sederajat sebanyak 17 anak atau $0.21 \%$ dan anak putus sekolah SMP/sederajat sebanyak 235 anak atau 6.80\%. Secara keseluruhan anak putus sekolah sebanyak 252 anak atau $2.15 \%$ dan anak tidak putus sekolah sebanyak 11484 anak atau 97.85\%. Gambar 2 merupakan persentase anak putus sekolah berdasarkan kabupaten/kota tempat anak tersebut tinggal.

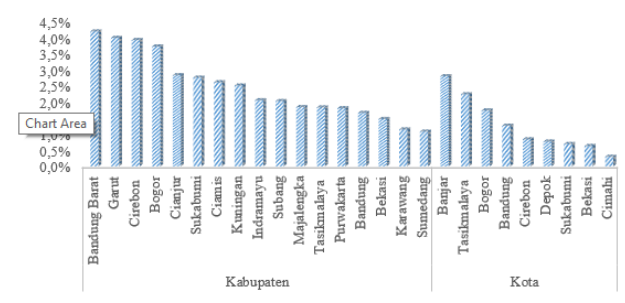

Gambar 1: Persentase anak putus sekolah berdasarkan kabupaten/kota

Peubah penjelas berdasarkan karakteristik sosial yaitu pendidikan terakhir kepala rumah tangga (KRT) dan jumlah anggota keluarga. Peubah pendidikan terakhir KRT terdiri dari lima kategori pada Gambar 3 terlihat bahwa sebagian besar pendidikan terakhir KRT adalah SD/sederajat (39\%), diikuti oleh SMA/sederajat (23\%), $\mathrm{SMP} /$ sederajat dan KRT yang tidak memiliki ijazah (15\%), dan perguruan tinggi (8\%). 
Peubah jumlah anggota keluarga terdiri dari dua kategori yaitu jumlah anggota keluarga kecil dan jumlah anggota keluarga lebih dari empat yang memiliki selisih tidak jauh berbeda yaitu masing-masing sebesar $53.2 \%$ dan $46.8 \%$.
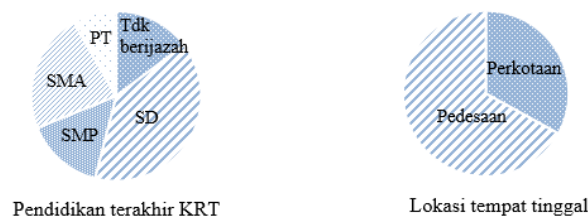

Gambar 2: Proporsi peubah penjelas

Peubah penjelas berdasarkan karakteristik ekonomi yaitu peubah pengeluaran rumah tangga per kapita per bulan terdiri dari dua kategori yaitu kurang dari garis kemiskinan (16.1\%) dan lebih dari garis kemiskinan (83.9\%). Garis kemiskinan merupakan penjumlahan dari garis kemiskinan makanan dan garis kemiskinan bukan makanan. Penduduk yang memiliki rata-rata pengeluaran per kapita per bulan di bawah garis kemiskinan dikategorikan sebagai penduduk miskin. Peubah penjelas berdasarkan karakteristik demografi terdiri dari peubah lokasi tempat tinggal, jenis kelamin anak, jenis kelamin KRT, dan umur KRT. Peubah lokasi tempat tinggal pada Gambar 3 terdiri dari dua kategori pedesaan dan perkotaan. Sebagian besar keluarga bertempat tinggal di pedesaan (67\%) dan bertempat tinggal di perkotaan (33\%). Peubah jenis kelamin anak laki-laki dan perempuan memiliki selisih tidak jauh berbeda yaitu $51.50 \%$ dan 48.50\%. Peubah jenis kelamin KRT memiliki proporsi yang sangat berbeda yaitu 810 atau 7\% KRT adalah perempuan, hal ini karena keluarga dengan status perkawinan yaitu cerai hidup maupun cerai mati dengan anak diasuh oleh ibu. Kisaran peubah umur KRT (tahun) yang paling muda yaitu berusia 23 tahun sedangkan yang paling tua yaitu 98 tahun dengan rata-rata umur yaitu 44.42 tahun.

\subsection{Deskripsi Anak Putus Sekolah Berdasarkan Peubah Penjelas}

Anak putus sekolah berdasarkan data peubah penjelas pada Gambar 4 terlihat bahwa peubah pendidikan terakhir KRT memiliki hubungan terbalik terhadap kejadian anak putus sekolah karena semakin tinggi pendidikan terakhir kepala rumah tangga maka semakin kecil kejadian anak putus sekolah. Hal ini dapat dikatakan bahwa karakteristik sosial berperan penting mengenai anak putus sekolah, sehingga semakin tinggi karakteristik sosial suatu keluarga maka semakin sedikit kejadian anak putus sekolah. Sedangkan untuk peubah jumlah anggota keluarga lebih dari empat, pengeluaran rumah tangga per kapita kurang dari garis kemiskinan, lokasi tempat tinggal di perkotaan, jenis kelamin anak laki-laki, dan jenis kelamin KRT perempuan yang memiliki persentase anak putus sekolah lebih tinggi dibandingkan dengan kategorinya masing-masing.

Gambar 6 merupakan boxplot data peubah umur KRT terhadap kejadian status sekolah anak yaitu putus sekolah dan tidak putus sekolah dengan rata-rata umur 47.302 tahun dan 44.362 tahun pada Tabel 4. Secara keseluruhan sebaran data peubah umur KRT menjulur ke kanan pada Gambar 5. Begitu pun pada Gambar 6 kedua boxplot memiliki sebaran data yang menjulur ke kanan, dengan kata lain rata-rata umur KRT lebih besar daripada median, sedangkan keragaman data pada status anak putus sekolah lebih kecil dibandingkan dengan status anak tidak putus sekolah. Terlihat juga bahwa pencilan data pada status anak putus sekolah lebih sedikit dan lebih rendah 


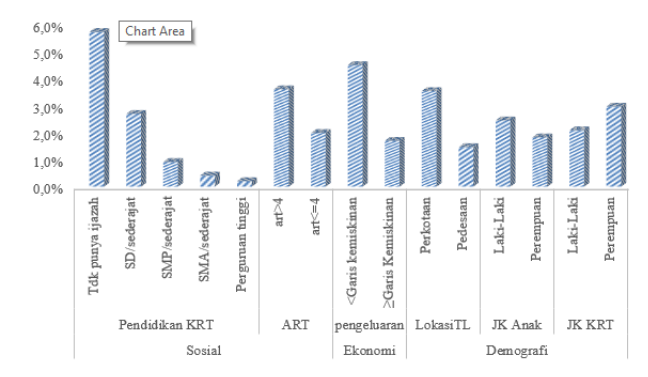

Gambar 3: Persentase anak putus sekolah berdasarkan data peubah penjelas

dibandingkan pencilan pada status anak tidak putus sekolah yang lebih banyak dan ekstrim, sehingga dapat dikatakan bahwa ada kecenderungan umur KRT berpengaruh terhadap kejadian anak putus sekolah.

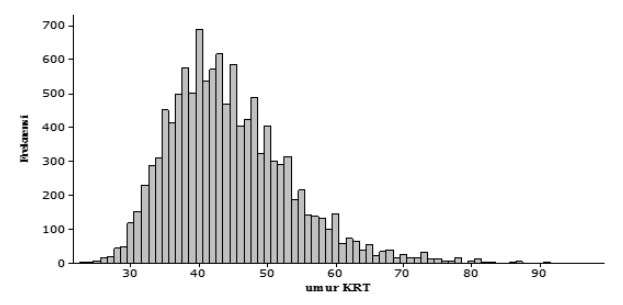

Gambar 4: Histogram peubah umur KRT

Tabel 2: Deskripsi peubah umur kepala rumah tangga terhadap status sekolah anak

Gambar 8 merupakan boxplot data peubah pengeluaran rumah tangga per kapita per bulan terhadap kejadian status anak, putus sekolah dan tidak putus sekolah. Secara keseluruhan sebaran data peubah pengeluaran per kapita per bulan menjulur ke kanan pada Gambar 7. Begitu pun pada Gambar 8 kedua boxplot memiliki sebaran data yang menjulur ke kanan, dengan kata lain rata-rata pengeluaran rumah tangga per kapita per bulan lebih besar daripada median, sedangkan keragaman data pada status anak putus sekolah lebih kecil dibandingkan dengan status anak tidak putus sekolah. Terlihat juga bahwa pencilan data pada status anak putus sekolah lebih sedikit dan lebih rendah dibandingkan pencilan status anak tidak putus sekolah yang sebagian besar bertempat tinggal di perkotaan dan pendidikan terakhir KRT perguruan tinggi, sehingga ada kemungkinan bahwa pengeluaran rumah tangga per kapita per bulan memberikan pengaruh terhadap kejadian anak putus sekolah terlihat dari rata-rata pengeluaran rumah tangga per kapita per bulan anak putus sekolah lebih rendah jika dibandingkan dengan anak tidak putus sekolah pada Tabel 5.

\section{Simpulan dan Saran}

Hasil pemodelan dengan regresi logistik terhadap kejadian anak putus sekolah pada tingkat SD/sederajat dan SMP/sederajat usia 7 hingga 15 tahun di Provinsi Jawa Barat, peubah-peubah yang mempengaruhi terjadinya anak putus sekolah pada taraf 


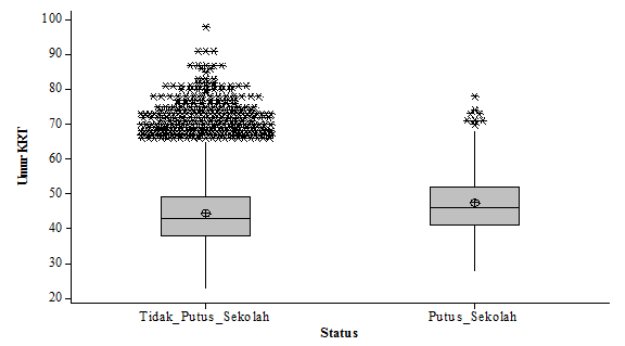

Gambar 5: Boxplot peubah umur KRT terhadap status sekolah anak

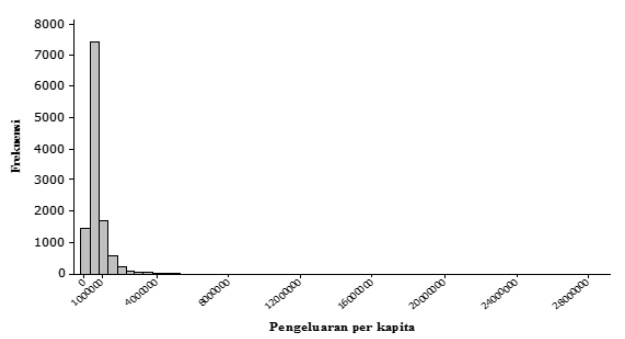

Gambar 6: Histogram peubah pengeluaran rumah tangga per kapita per bulan

nyata $5 \%$ adalah pendidikan terakhir KRT, pengeluaran rumah tangga per kapita per bulan, lokasi tempat tinggal, jenis kelamin anak, dan jumlah anggota rumah tangga. Berdasarkan nilai rasio odds, anak sekolah dengan pendidikan terakhir KRT yang rendah, pengeluaran rumah tangga per kapita per bulan kurang dari garis kemiskinan, lokasi tempat tinggal di perkotaan, anak laki-laki, dan jumlah anggota rumah tangga lebih dari empat memiliki kecenderungan yang lebih tinggi untuk putus sekolah. Model yang dihasilkan cukup baik digunakan untuk melakukan pendugaan kejadian anak putus sekolah dengan nilai sensitivitas $70.20 \%$, tingkat ketepatan klasifikasi keseluruhan $67.40 \%$, serta luas area di bawah kurva ROC sebesar $76.42 \%$. 
Tabel 3: Deskripsi peubah pengeluaran rumah tangga per kapita terhadap status sekolah anak

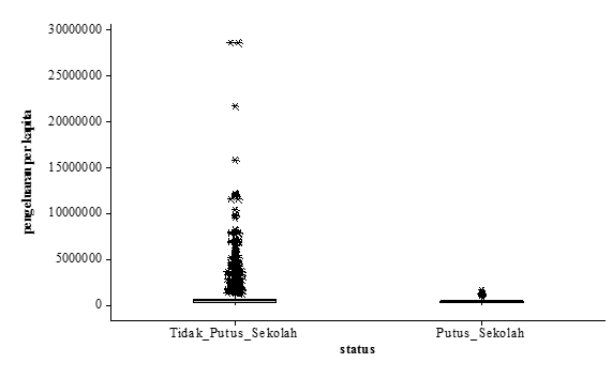

Gambar 7: Boxplot peubah pengeluaran rumah tangga per kapita per bulan 